\title{
Optimization of radiotherapy for neck carcinoma metastasis from unknown primary sites: a meta-analysis
}

\author{
Xiaomei Liu ${ }^{1, *}$, Dianhe $\mathrm{Li}^{1, *}, \mathrm{Na} \mathrm{Li}^{1}$, Xiaoxia Zhu ${ }^{1}$ \\ ${ }^{1}$ Department of Radiation Oncology, Nanfang Hospital, Southern Medical University, Guangzhou 510515, China \\ *These authors contributed equally to this work
}

Correspondence to: Xiaoxia Zhu, email: zhuxx01@126.com

Keywords: neck carcinoma metastasis, unknown primary, NCUP, radiotherapy, meta-analysis

Received: June 09, 2016

Accepted: October 14, 2016

Published: October 24, 2016

\section{ABSTRACT}

This meta-analysis was designed to evaluate radiotherapy (RT) options preferable for neck cancer metastases from unknown primary sites (NCUP). Relevant articles published up through September 2015 were selected from EMBASE, Cochrane, PubMed and Web of Science. Thirty-three articles were identified, and relative risks (RRs) and $\mathbf{9 5 \%}$ CIs for all pre-specified endpoints were calculated. Surgery plus RT showed an advantage for 5-year overall survival (OS) (RR 0.66, 95\% CI 0.52-0.83, $p=0.0004$ ) and neck recurrence $(N R)(R R=0.74,95 \% C I 0.59-0.92, p=0.008)$ compared to RT alone. The RRs for NR, primary tumor emergence (PTE), and 5-year disease free survival (DFS) for bilateral neck compared to ipsilateral neck irradiation were $\mathbf{0 . 6 1}$ (95\% CI 0.41-0.91, $p=0.01), 0.44(95 \%$ CI $0.26-0.77, p=0.004)$, and 0.81 (95\% CI 0.64-1.03, $p=0.09$ ), respectively. Irradiation of the neck plus potential primary tumor sites (PPTS) showed a benefit for 5-year DFS (RR 0.75, 95\% CI 0.61-0.92, $p=0.005)$, NR (RR = 0.72, 95\% CI 0.56-0.92, $p=0.009)$, and PTE $(R R=0.23,95 \%$ CI 0.12-0.45, $p<0.0001$ ) compared to neck-only irradiation. Adverse events occurred more frequently with bilateral neck plus PPTS irradiation. For NCUP, surgery plus RT of the bilateral neck and PPTS was associated with greater improvement of clinical outcomes.

\section{INTRODUCTION}

Neck cancer metastasis with an unknown primary site (NCUP) presents in patients with neck lymph node involvement in the absence of an identifiable primary tumor [1-3]. The histopathology of NCUP consists of squamous cell carcinoma, adenocarcinoma, and other undifferentiated carcinomas [1-3]. The often-extensive diagnostic workup to identify the primary site can include physical examination, chest X-ray, endoscopy, biopsy, computed tomography (CT) or magnetic resonance imaging (MRI), and positron emission tomography (PET). Nonetheless, in approximately $2 \%$ to $10 \%$ of NCUP cases the primary site remains unidentified [1-12].

NCUP is thought to be potentially curable [2], but the data addressing the therapeutic protocols and outcomes of NCUP treatment are limited and controversial. The proposed treatment modalities include surgery alone, radiotherapy (RT) alone, and a combination of RT and surgery. Opinions on the field design for RT also vary. Some investigators have recommended involved-field irradiation, such as ipsilateral neck irradiation only [7, 11-14], while others suggest extended field irradiation, including prophylactic irradiation of potential head and neck mucosal sites and both sides of the neck $[1,4,6,15]$. Differences in treatment strategy and patient selection have led to inconsistent results. Consequently, the reported 5-year overall survival (OS) rates for patients with NCUP range from $16 \%$ to $86 \%$, and the local control rates range from $37 \%$ to $91 \%$. The present meta-analysis was performed in an effort to identify the optimal treatment regimen for NCUP, focusing in particular on the optimal way to schedule RT.

\section{RESULTS}

Description of selected studies and quality assessment

A total of 787 articles were identified, of which 33 articles qualified for inclusion. The flow diagram for 
study selection is shown in Figure 1. The characteristics of the included studies are summarized in Tables 1 and 2. Although methods for managing missing data are not adequately described in some studies, none of the included studies had a NOS $<6$, which suggests all were of high quality.

\section{RT alone versus RT combined with surgery}

Eighteen studies $[2,5,9,10,16-29]$, with a total of 1582 patients, were included in this analysis. Compared to RT alone, the combination of RT and surgery significantly improved 5-year OS $(\mathrm{RR}=0.66,95 \%$ CI $0.52-0.83$, $p=0.0004$ ) (Figure 2A). The benefit to 5-year DFS showed a similar trend $(\mathrm{RR}=0.81,95 \%$ CI $0.62-1.07$, $p=0.13$ ) (Figure $2 \mathrm{~B})$, though this did not reach statistical significance. Additionally, surgery in combination with RT was associated with a significantly decreased NR rate $(\mathrm{RR}=0.74,95 \%$ CI $0.59-0.72, p=0.008)$ (Figure 2D) and an increased $\mathrm{CR}$ rate $(\mathrm{RR}=0.37,95 \% \mathrm{CI} 0.21-0.64$, $p=0.0003$ ) (Figure 2C).

\section{Ipsilateral versus bilateral neck irradiation}

Sixteen studies [1, 3-7, 11-15, 23, 20-33] with a total of 1449 patients, meeting the inclusion criteria were selected for this analysis (Table B). Bilateral neck irradiation contributed to better local control with a lower NR rate $(\mathrm{RR}=0.61,95 \% \mathrm{CI} 0.41-0.91, p=0.01)$ (Figure $3 \mathrm{~A})$ and $\mathrm{PTE}$ rate $(\mathrm{RR}=0.44,95 \% \mathrm{CI} 0.26-0.77$, $p=0.004$ ) (Figure 3B). This was especially true for contralateral neck control $(\mathrm{RR}=0.30,95 \%$ CI $0.15-0.59$,

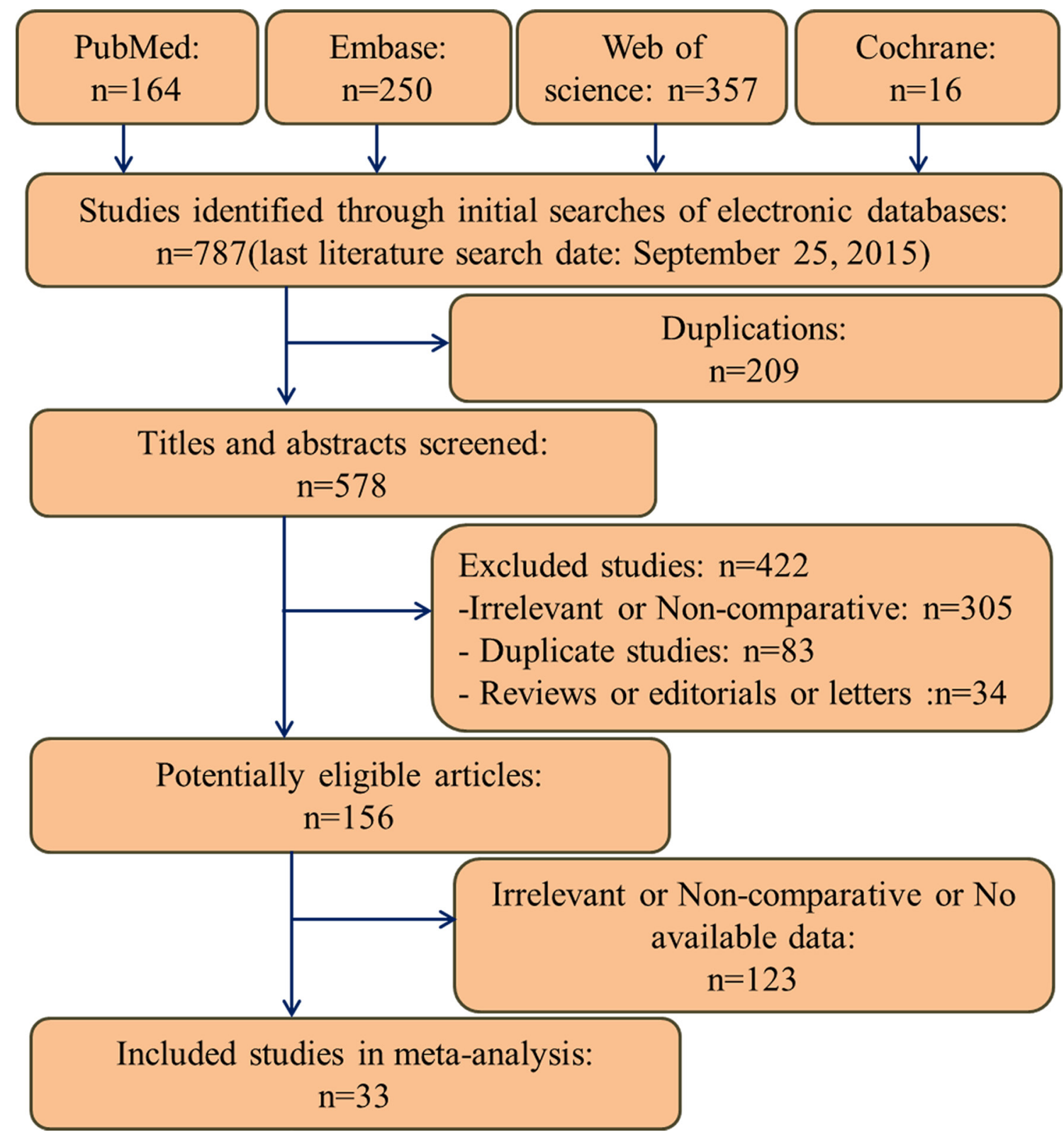

Figure 1: Flow diagram of studies identification and selection. 
Table 1: Baseline characteristics of the included studies

\begin{tabular}{|c|c|c|c|c|c|c|c|c|c|c|c|}
\hline Study & $\begin{array}{c}\text { Patients } \\
\text { No. }\end{array}$ & Age(year) & $\begin{array}{l}\text { Study } \\
\text { period }\end{array}$ & Country & Follow up & $\begin{array}{l}\text { Gender } \\
\text { (Male/ } \\
\text { Female) }\end{array}$ & Design & $\begin{array}{l}\text { Quality } \\
\text { score }\end{array}$ & Histology & $\begin{array}{c}\text { *Nodal stage } \\
\text { (NX-1/ } \\
\text { N2-3) }\end{array}$ & $\begin{array}{l}\text { Nodal level } \\
\text { (I-II/III-IV) }\end{array}$ \\
\hline 1973Jesse & 184 & NA & $1948-1968$ & USA & $>3 Y$ & NA & $\mathrm{R}$ & 7 & 1,3 & $63 / 121$ & $162 / 48$ \\
\hline 1975Fried & 43 & NA & 1958-1969 & USA & NA & $2: 1$ & $\mathrm{R}$ & 6 & $1,2,3$ & NA & NA \\
\hline 1979Nordstrom & 39 & $60(13-88)$ & $1960-1973$ & USA & NA & $40 / 11$ & $\mathrm{R}$ & 6 & $1,2,3$ & $8 / 43$ & NA \\
\hline 1981Leipzig & 32 & $51(22-76)$ & 1969-1977 & USA & NA & $2: 1$ & $\mathrm{R}$ & 7 & 1 & $14 / 18$ & NA \\
\hline 1986Carlson & 93 & NA & 1968-1980 & USA & $>3 Y$ & $70 / 23$ & $\mathrm{R}$ & 7 & $1,2,3$ & $41 / 52$ & $61 / 32$ \\
\hline 1987Bataini & 138 & $57.5(15-82)$ & 1960-1980 & USA & $>5 \mathrm{Y}$ & $117 / 21$ & $\mathrm{R}$ & 8 & 1 & $45 / 93$ & NA \\
\hline 1990Glynne & 58 & $61(12-85)$ & $1954-1986$ & UK & $35(4-300) \mathrm{M}$ & $53 / 34$ & $\mathrm{R}$ & 7 & 1,3 & $11 / 76$ & NA \\
\hline 1990Harper & 69 & $58.5(26-91)$ & 1964-1986 & Australia & $>2 Y$ & $58 / 11$ & $\mathrm{R}$ & 8 & 1 & $18 / 51$ & NA \\
\hline 1990Marcial & 72 & $58.5(24-85)$ & $1965-1987$ & USA & NA & $50 / 22$ & $\mathrm{R}$ & 6 & 1,3 & $12 / 60$ & $35 / 37$ \\
\hline 1995Weir & 144 & $60(28-90)$ & $1970-1986$ & Canada & $3.5(4-15) \mathrm{Y}$ & $110 / 34$ & $\mathrm{R}$ & 8 & $1,2,3$ & $79 / 65$ & NA \\
\hline 1997Reddy & 52 & $59(30-79)$ & 1974-1989 & USA & $>5 \mathrm{Y}$ & $50 / 2$ & $\mathrm{R}$ & 9 & 1 & $9 / 43$ & NA \\
\hline $\begin{array}{l}1997 \\
\text { Sinnathamby }\end{array}$ & 67 & $62(29-84)$ & 1983-1992 & Australia & 7M-7Y & $51 / 18$ & $\mathrm{R}$ & 8 & 1,3 & $9 / 60$ & NA \\
\hline 1997van der & 44 & $66(20-86)$ & 1974-1991 & Netherlands & 7.3Y(2-18.8) & $35 / 9$ & $\mathrm{R}$ & 7 & $1,2,3$ & $4 / 40$ & NA \\
\hline 1998Colletier & 136 & $59(25-83)$ & 1968-1992 & Canada & $58(3-267) \mathrm{M}$ & $103 / 33$ & $\mathrm{R}$ & 7 & 1 & $41 / 95$ & $104 / 32$ \\
\hline 1998Strojan & 56 & $56(33-81)$ & 1975-1994 & Slovenia & $8.6(1.6-17.8) \mathrm{Y}$ & $50 / 6$ & $\mathrm{R}$ & 8 & 1 & $6 / 50$ & $39 / 17$ \\
\hline 2000Grau & 352 & $62(18-92)$ & $1975-1995$ & Denmark & $5 \mathrm{Y}$ & $248 / 104$ & $\mathrm{R}$ & 7 & 1,3 & $48 / 225$ & $277 / 0$ \\
\hline 2000McMahon & 34 & $67(45-84)$ & 1987-1998 & Australia & $2.7(0.9-6.7) \mathrm{Y}$ & $28 / 10$ & $\mathrm{R}$ & 8 & 1 & $6 / 32$ & $31 / 7$ \\
\hline 2002Tong & 45 & 57(29-91) & 1988-1998 & Hong Kong & $79 \mathrm{M}(27-110)$ & $37 / 8$ & $\mathrm{R}$ & 7 & $1,2,3$ & $7 / 38$ & $20 / 25$ \\
\hline 2002Yalin & 114 & $48(18-78)$ & 1976-1988 & China & NA & NA & $\mathrm{R}$ & 7 & $1,2,3$ & $33 / 81$ & NA \\
\hline 2002Zuur & 14 & $\begin{array}{l}62.6 \\
(34.7-82.8)\end{array}$ & 1975-1999 & Netherlands & $2-67 \mathrm{M}$ & $8 / 8$ & $\mathrm{R}$ & 7 & 1,2 & $2 / 13$ & $3 / 12$ \\
\hline 2006Boscolo & 79 & $64.7 \pm 9.3$ & 1980-2001 & Italy & $15 \mathrm{Y}$ & $69 / 13$ & $\mathrm{R}$ & 8 & 1 & $10 / 62$ & $60 / 12$ \\
\hline 2007Aslani & 61 & $57(37-87)$ & $1987-2002$ & Canada & $31(7-168) \mathrm{M}$ & $49 / 12$ & $\mathrm{R}$ & 7 & 1,3 & $16 / 45$ & $53 / 8$ \\
\hline 2007Beldi & 113 & $59.3(23-88)$ & 1980-2004 & Italy & NA & $93 / 20$ & $\mathrm{R}$ & 7 & $1,2,3$ & $21 / 92$ & $83 / 30$ \\
\hline 2008Huang & 31 & $63.3(36-84)$ & $1980-2000$ & Taiwan & NA & $35 / 13$ & $\mathrm{R}$ & 8 & 1 & $3 / 45$ & $39 / 9$ \\
\hline 2009Ligey & 95 & $59(38-80)$ & 1990-2007 & France & $\begin{array}{l}3.3 \mathrm{Y} \\
(5 \mathrm{M}-11.7 \mathrm{Y})\end{array}$ & $84 / 11$ & $\mathrm{R}$ & 7 & 1,3 & $25 / 70$ & 77/18 \\
\hline 2009Lu & 60 & $53(23-81)$ & 1989-2003 & China & 58(10-135)M & $46 / 14$ & $\mathrm{R}$ & 8 & 1 & $10 / 50$ & $44 / 16$ \\
\hline 2009Rodel & 58 & $55(37-77)$ & 1980-2004 & Germany & $83.5 \mathrm{M}(24-162)$ & $58 / 10$ & $\mathrm{R}$ & 7 & $1,2,3$ & 9/49 & $55 / 3$ \\
\hline 2011Chen & 60 & $60(42-90)$ & 2001-2009 & USA & $30 \mathrm{M}(3-90)$ & $39 / 21$ & $\mathrm{R}$ & 8 & 1 & $5 / 55$ & $51 / 9$ \\
\hline 2011Wallace & 179 & $61(26-89)$ & 1990-2006 & USA & $4.2 \mathrm{Y}(0.2-25.4)$ & $157 / 22$ & $\mathrm{R}$ & 8 & 1 & $18 / 161$ & NA \\
\hline 2012Fakhrian & 65 & $60(39-90)$ & 1988-2009 & Germany & 64(3-219)M & $52 / 13$ & $\mathrm{R}$ & 9 & 1,3 & $14 / 51$ & $46 / 19$ \\
\hline 2012Perkins & 46 & $60(40-82)$ & 1989-2008 & USA & $4.6 \mathrm{Y}(7 \mathrm{M}-18 \mathrm{Y})$ & NA & $\mathrm{R}$ & 9 & 1 & $3 / 43$ & NA \\
\hline 2014Demiroz & 41 & $53(38-72)$ & 1994-2009 & USA & $11-126 \mathrm{M}$ & $37 / 4$ & $\mathrm{R}$ & 9 & 1 & $4 / 37$ & $33 / 8$ \\
\hline 2015Straetmans & 46 & NA & $1997-2010$ & $\begin{array}{l}\text { Netherlands, } \\
\text { Germany }\end{array}$ & NA & $44 / 7$ & $\mathrm{R}$ & 8 & 1 & $4 / 42$ & NA \\
\hline
\end{tabular}

*According to UICC/AJCC staging system. $\mathrm{R}=$ retrospective; $\mathrm{Y}=$ year; $\mathrm{M}=$ month; $\mathrm{NA}=$ Not available;

1 = squamous cell carcinoma; 2 = adenocarcinoma; 3 = undifferentiated carcinoma

$p<0.0005$ ) (Figure 3C). Moreover, when compared to ipsilateral irradiation, bilateral neck irradiation showed a potential survival advantage with greater 5-year $\mathrm{OS}(\mathrm{RR}=0.86$, 95\% CI 0.61-1.22, $p=0.40$ ) (Figure 3D) and 5-year DFS (RR $=0.81,95 \%$ CI $0.64-1.03, p=0.09)$ (Figure 3E), although this benefit was not statistically significant.

\section{Neck-only versus neck plus PPTS irradiation}

Fifteen studies $[1-8,11-13,15,22,30,33]$, with a total of 1347 patients, fulfilled the inclusion criteria and were included in this analysis. As compared to neckonly irradiation, superior 5-year DFS (RR $0.75,95 \%$ CI $0.61-0.92, p=0.005$ ) (Figure 4A) and a trend toward increased 5-year OS $(\mathrm{RR}=0.70,95 \%$ CI $0.48-1.01$, $p=0.06$ ) (Figure 4B) were observed in patients treated with neck and PPTS irradiation. In addition, neck and PPTS irradiation had a significant advantage for reducing $\mathrm{NR}$ rate $(\mathrm{RR}=0.72,95 \%$ CI $0.56-0.92, p=0.009)$ (Figure $4 \mathrm{C}), \mathrm{CNR}$ rate $(\mathrm{RR}=0.23,95 \%$ CI $0.12-0.45$, $p<0.0001)$ (Figure 4D) and PTE rate $(\mathrm{RR}=0.59,95 \% \mathrm{CI}$ $0.39-0.89, p=0.01$ ) (Figure 4E). 
Table 2: Baseline characteristics of the treatments of the included studies

\begin{tabular}{|c|c|c|c|c|c|c|}
\hline \multirow[b]{2}{*}{ Study } & \multirow{2}{*}{$\begin{array}{c}\text { Patients } \\
\text { No. }\end{array}$} & \multirow{2}{*}{$\begin{array}{c}\text { Chemotherapy } \\
\text { Patients No. }\end{array}$} & \multicolumn{2}{|r|}{ Radiotherapy } & \multicolumn{2}{|c|}{ Surgery } \\
\hline & & & $\begin{array}{c}\text { Patients } \\
\text { No. }\end{array}$ & Treatment volume & $\begin{array}{c}\text { Patients } \\
\text { No. }\end{array}$ & $\begin{array}{l}\text { Types of } \\
\text { surgery }\end{array}$ \\
\hline 1973Jesse & 184 & 0 & 80 & BN+PPTS,IN+PPTS,BN,IN & 132 & $\mathrm{ND}, \mathrm{E}$ \\
\hline 1975Fried & 43 & 0 & 43 & BN+PPTS,IN+PPTS,BN,IN & 16 & ND \\
\hline 1979Nordstrom & 39 & 0 & 39 & BN+PPTS,IN+PPTS,IN & 34 & ND \\
\hline 1981Leipzig & 32 & 0 & 24 & $\mathrm{BN}+\mathrm{PPTS}, \mathrm{IN}+\mathrm{PPTS}, \mathrm{BN}, \mathrm{IN}$ & 24 & ND \\
\hline 1986Carlson & 93 & 0 & 93 & BN+PPTS,IN+PPTS,BN,IN & 70 & $\mathrm{ND}, \mathrm{E}$ \\
\hline 1987Bataini & 138 & 0 & 138 & $\mathrm{BN}+\mathrm{PPTS}, \mathrm{BN}, \mathrm{IN}$ & 48 & ND \\
\hline 1990Glynne & 58 & 1 & 58 & BN+PPTS,IN+PPTS,BN,IN & 6 & ND \\
\hline 1990Harper & 69 & 0 & 69 & $\mathrm{BN}+\mathrm{PPTS}, \mathrm{IN}+\mathrm{PPTS}, \mathrm{BN}, \mathrm{IN}$ & 30 & ND \\
\hline 1990Marcial & 72 & 0 & 72 & $\mathrm{BN}+\mathrm{PPTS}, \mathrm{IN}+\mathrm{PPTS}, \mathrm{BN}, \mathrm{IN}$ & 31 & $\mathrm{ND}, \mathrm{E}$ \\
\hline 1995Weir & 144 & 0 & 144 & $\mathrm{BN}+\mathrm{PPTS}, \mathrm{IN}+\mathrm{PPTS}, \mathrm{BN}, \mathrm{IN}$ & 71 & $\mathrm{E}$ \\
\hline 1997Reddy & 52 & 0 & 52 & $\mathrm{BN}+\mathrm{PPTS}, \mathrm{IN}$ & 39 & $\mathrm{ND}, \mathrm{E}$ \\
\hline 1997Sinnathamby & 67 & 0 & 63 & $\mathrm{BN}, \mathrm{IN}$ & 44 & $\mathrm{ND}, \mathrm{E}$ \\
\hline 1997van der & 44 & 0 & 44 & $\mathrm{BN}+\mathrm{PPTS}, \mathrm{IN}+\mathrm{PPTS}, \mathrm{BN}, \mathrm{IN}$ & 31 & $\mathrm{ND}, \mathrm{E}$ \\
\hline 1998Colletier & 136 & 0 & 136 & BN+PPTS,IN+PPTS,BN,IN & 136 & $\mathrm{ND}, \mathrm{E}$ \\
\hline 1998Strojan & 56 & 0 & 56 & BN+PPTS,IN+PPTS,IN & 56 & $\mathrm{ND}, \mathrm{E}$ \\
\hline 2000Grau & 352 & 0 & 250 & $\mathrm{BN}+\mathrm{PPTS}, \mathrm{IN}$ & 169 & $\mathrm{ND}, \mathrm{E}$ \\
\hline 2000McMahon & 34 & 0 & 34 & $\mathrm{BN}+\mathrm{PPTS}, \mathrm{IN}$ & 34 & ND \\
\hline 2002Tong & 45 & 8 & 36 & $\mathrm{BN}+\mathrm{PPTS}$ & 13 & $\mathrm{ND}, \mathrm{E}$ \\
\hline 2002Yalin & 114 & 39 & 76 & $\mathrm{BN}+\mathrm{PPTS}, \mathrm{IN}+\mathrm{PPTS}, \mathrm{BN}, \mathrm{IN}$ & 24 & $\mathrm{ND}, \mathrm{E}, \mathrm{T}$ \\
\hline 2002Zuur & 14 & 0 & 14 & $\mathrm{BN}+\mathrm{PPTS}, \mathrm{IN}+\mathrm{PPTS}, \mathrm{BN}, \mathrm{IN}$ & 7 & ND \\
\hline 2006Boscolo & 79 & 0 & 79 & $\mathrm{BN}+\mathrm{PPTS}, \mathrm{IN}$ & 50 & ND \\
\hline 2007Aslani & 61 & 0 & 61 & $\mathrm{BN}+\mathrm{PPTS}, \mathrm{BN}, \mathrm{IN}$ & 29 & $\mathrm{ND}, \mathrm{E}$ \\
\hline 2007Beldi & 113 & 21 & 113 & $\mathrm{BN}+\mathrm{PPTS}, \mathrm{BN}, \mathrm{IN}$ & 99 & $\mathrm{ND}, \mathrm{E}$ \\
\hline 2008Huang & 31 & 16 & 31 & $\mathrm{BN}+\mathrm{PPTS}$ & 30 & $\mathrm{ND}$ \\
\hline 2009Ligey & 95 & 43 & 95 & $\mathrm{BN}+\mathrm{PPTS}, \mathrm{IN}+\mathrm{PPTS}, \mathrm{BN}, \mathrm{IN}$ & 79 & ND \\
\hline $2009 \mathrm{Lu}$ & 60 & 14 & 60 & $\mathrm{BN}+\mathrm{PPTS}, \mathrm{BN}, \mathrm{IN}$ & 9 & $\mathrm{E}$ \\
\hline 2009Rodel & 58 & 22 & 50 & $\mathrm{BN}+\mathrm{PPTS}, \mathrm{IN}$ & 53 & ND \\
\hline 2011Chen & 60 & 32 & 60 & BN+PPTS,IN+PPTS,IN & 45 & $\mathrm{ND}, \mathrm{E}$ \\
\hline 2011Wallace & 179 & 13 & 179 & $\mathrm{BN}+\mathrm{PPTS}, \mathrm{IN}+\mathrm{PPTS}, \mathrm{IN}$ & 109 & ND \\
\hline 2012Fakhrian & 65 & 19 & 65 & $\mathrm{BN}+\mathrm{PPTS}, \mathrm{IN}$ & 51 & $\mathrm{ND}, \mathrm{E}$ \\
\hline 2012Perkins & 46 & 14 & 46 & $\mathrm{BN}+\mathrm{PPTS}, \mathrm{IN}+\mathrm{PPTS}, \mathrm{BN}, \mathrm{IN}$ & 40 & $\mathrm{ND}, \mathrm{E}$ \\
\hline 2014Demiroz & 41 & 25 & 41 & $\mathrm{BN}+\mathrm{PPTS}, \mathrm{BN}, \mathrm{IN}$ & 22 & ND \\
\hline 2015Straetmans & 51 & 8 & 48 & $\mathrm{BN}+\mathrm{PPTS}, \mathrm{BN}, \mathrm{IN}$ & 51 & ND \\
\hline
\end{tabular}

Abbreviations: $\mathrm{BN}=$ Bilateral neck; $\mathrm{IN}=$ Ipsilateral neck; PPTS = Potential primary tumor sites.

Neck dissection $=$ ND, Excision $=E$, Thyroidectomy $=\mathrm{T}$.

\section{Toxic effects of different radiotherapeutic regimens}

Only two of the included studies $[11,15]$ compared toxicities between ipsilateral neck irradiation and bilateral neck plus PPTS irradiation, and the toxicity data could only be assessed for severe acute toxicity and xerostomia. We found there was an increased risk of severe acute toxicity $(\mathrm{RR}=1.91,95 \% \mathrm{CI} 1.26-2.88, p=0.002)$ (Supplementary Figure S1A) and xerostomia $(\mathrm{RR}=6.82$, 95\% CI 0.96-48.55, $p=0.06$ ) (Supplementary Figure $\mathrm{S} 1 \mathrm{~B}$ ) in the group with bilateral neck and PPTS irradiation. 


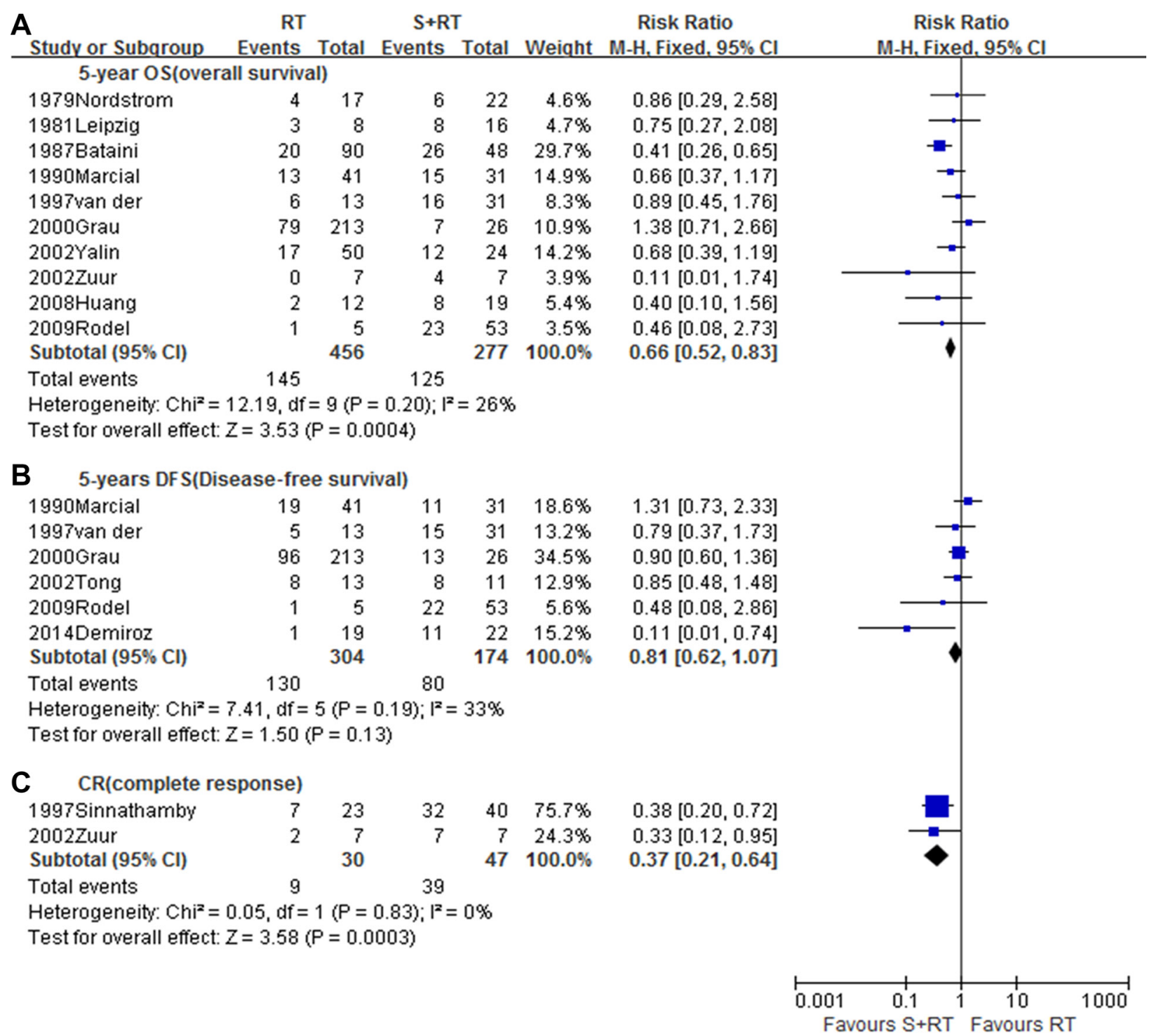

D

$\mathrm{S}+\mathrm{RT}$

RT

Risk Ratio

Study or Subgroup Events Total Events Total Weight M-H. Fixed. 95\% Cl

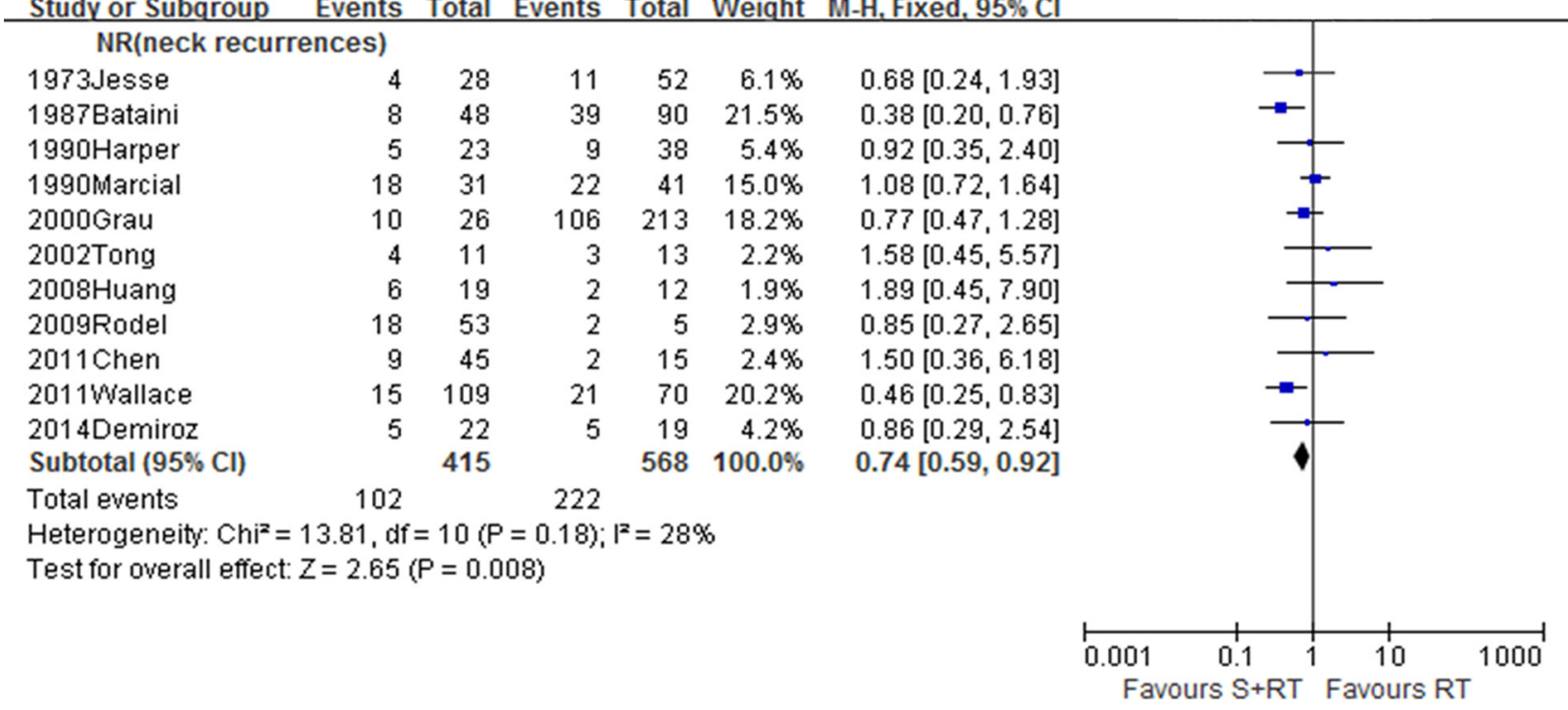

Figure 2: Meta-analysis of (A) 5-year OS, (B) 5-year DFS,(C) CR, (D) NR between RT alone and RT combined with surgery. S, Surgery; RT, Radiotherapy. 


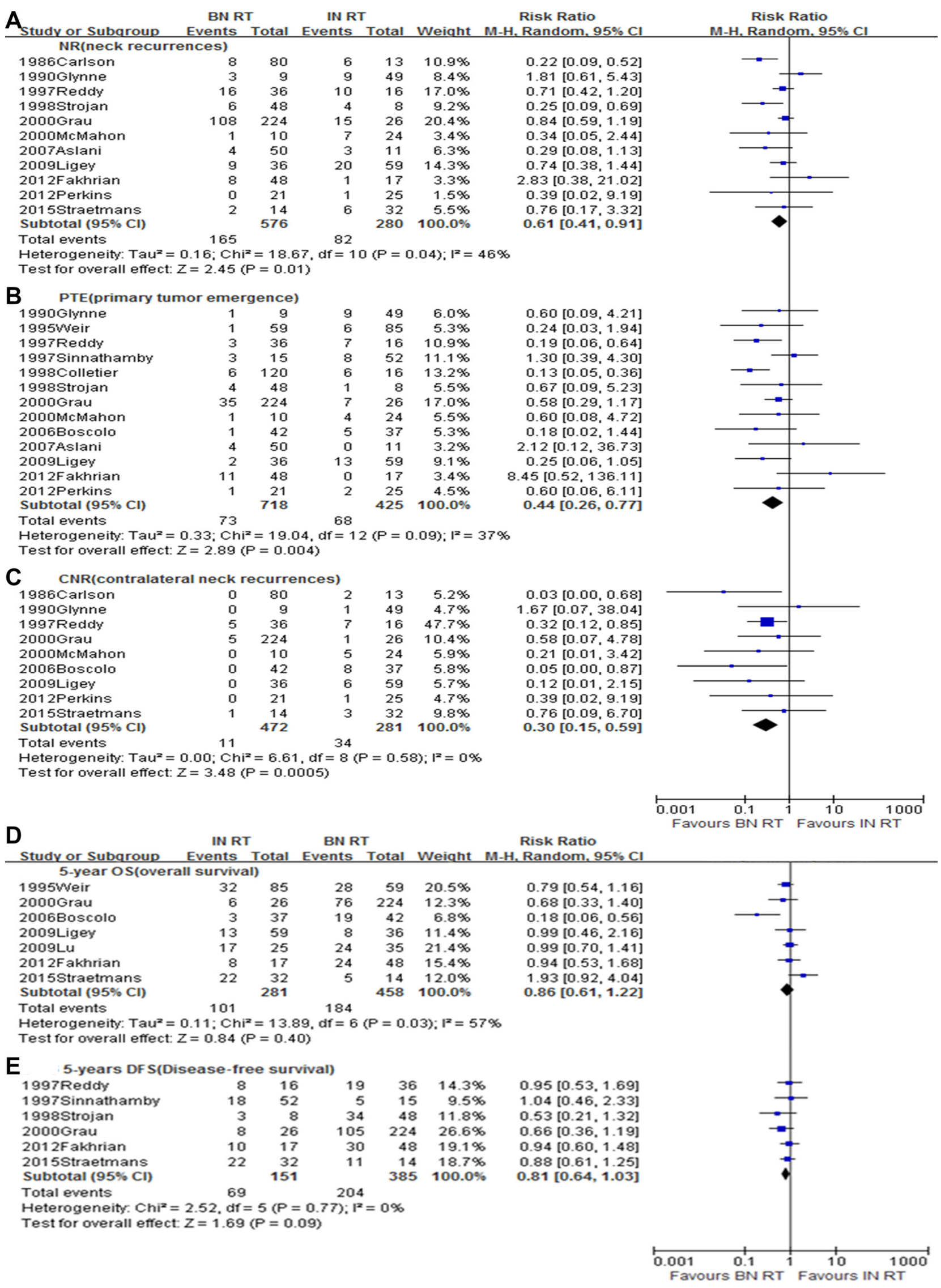

Figure 3: Meta-analysis of (A) NR, (B) PTE, (C) CNR, (D) 5-year OS, and (E) 5-year DFS between ipsilateral neck irradiation and bilateral neck irradiation. BN, Bilateral neck; IN, Ipsilateral neck; RT, Radiotherapy. 


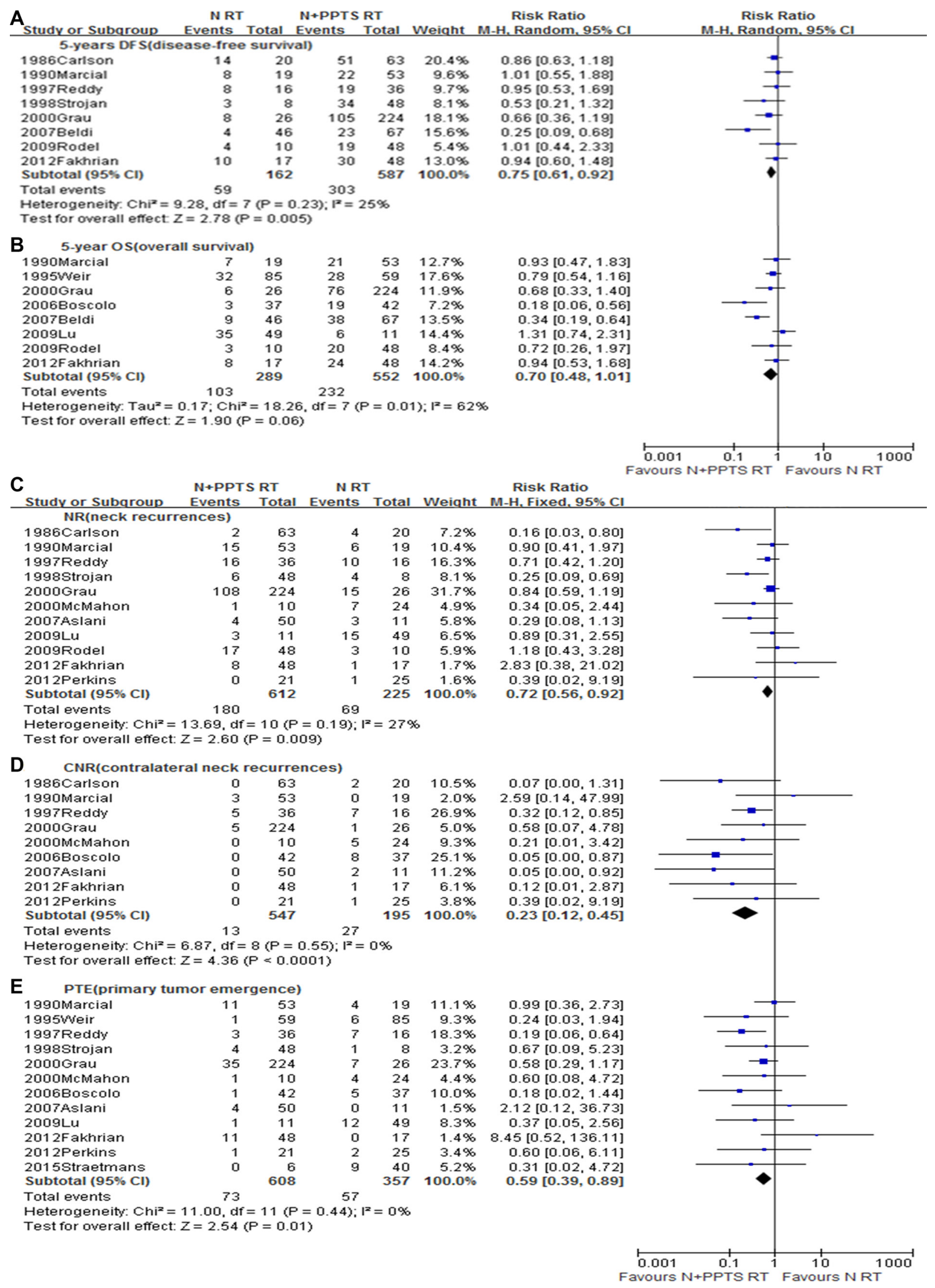

Figure 4: Meta-analysis of (A) NR, (B) PTE, (C) CNR, (D) 5-year OS, and (E) 5-year DFS between neck only irradiation and neck plus potential primary tumour sites irradiation. N, Neck only; N+PPTS, Neck plus potential primary mucosa sites; RT, Radiotherapy. 


\section{DISCUSSION}

Optimal treatment for patients with NCUP remains uncertain. The incidence of NCUP is about 3 cases per $1,000,000$ per year. Its rarity makes randomized and prospective studies unavailable, and leaves clinicians with only small retrospective studies for clinical decision making. To the best of our knowledge, this study is the first meta-analysis with a focus on comparing the therapeutic efficacies of different treatment regimens, and on providing a higher level of evidence for optimizing the RT schedule in NCUP.

Some studies held that surgery plus RT resulted in a higher probability of cure $[2,5,9,27,28]$, while others reported that the outcome of surgery plus RT were similar to those of definitive RT alone, but with a higher risk of severe complications $[19,25,29]$. We therefore first performed a comparison of RT alone with RT plus surgery. The pooled analysis demonstrated that RT plus surgery was associated with a greater 5-year OS rate than RT alone. Moreover, there was a beneficial trend toward a higher 5 -year DFS, though the effect was not significant. The higher CR rate and lower NR rate is also consistent with a survival benefit from the combination of surgery and RT.

For neck-irradiation settings, the current guidelines suggest treating the involved lymph node field [34]. However, some reports indicate that patients administered RT to the bilateral neck nodes appeared to have greater local control and higher survival rates than those who received only ipsilateral irradiation $[1,4,6,15]$. In the present pooled analysis, significantly less contralateral cervical recurrence or emergence of a primary tumor was noted in patients receiving bilateral irradiation, and there was trend toward increased 5-year OS and DFS. These findings suggest that current guidelines recommending the involved lymph node field as the standard RT schedule may need to be re-evaluated for the NCUP setting.

As to the value of irradiation of the PPTS, although current guidelines recommend it as routine consideration for inclusion in the target volume [34], conclusions drawn from currently available evidence are controversial. Some studies have shown a higher 5-year OS rate and better regional control with addition of irradiation of potential head and neck mucosal sites of cancer growth $[1,4-6,8,13$, 15], whereas, other trials observed that mucosal irradiation reduced both the emergence of primary tumors and regional recurrence, but did not affect OS $[3,7,12]$. In the pooled analysis of all these trials, not only was an advantage for regional control validated, so was a survival benefit in patients treated with irradiation of the neck and PPTS.

We also evaluated the toxic effects of different RT regimens. Because the data were limited, we only assessed severe acute toxicities and xerostomia. We found a significantly higher risk of these adverse events in the RT to the bilateral neck plus PPTS group. However, it is believed that these severe acute toxicities are clinically manageable, and xerostomia could be minimized by application of intensity modulated RT (IMRT) [11, 15].

There were several limitations to this study. First, all the included studies were retrospective and the sample groups were small. There was not sufficient data to perform subgroup analyses based on lymph node levels, lymph node stages, histological types, sequence of surgery and RT, or radiation dosage. Second, these studies were performed over a long time-span. Consequently, the techniques for delivering RT were varied, and precision RT techniques, such as 3-D conformal RT and IMRT, were not yet broadly applied. This could result in an underestimation of the actuarial effect of RT. To address these issues, future multicenter RCTs are needed.

\section{MATERIALS AND METHODS}

\section{Literature search and selection}

Two authors (X.M.L. and X.X.Z.) independently carried out systematic literature searches of EMBASE, Cochrane, Pubmed and Web of Science before September 25,2015 . The following terms were used: occult primary, unknown primary, neck lymph node, cervical lymph node, metastatic, metastases, cancer, neoplasm, tumor, carcinoma, radiotherapy, irradiation, radiation.

Studies meeting the following selection criteria were included. (1) Study population: patients with cervical lymph node metastases from unknown primary sites, and with no cancer history. (2) Study design: comparative studies comparing RT alone with a combination of RT and surgery (radical neck dissection, selective neck dissection, or excisional biopsy); comparing ipsilateral irradiation with bilateral irradiation; or comparing neckonly irradiation with neck and potential primary tumor site (PPTS) (nasopharynx, oropharynx, larynx, and/ or hypopharynx) irradiation. (3) Language: English. (4) Studies with available data on at least one of the pre-specified endpoints: 5-year OS, 5-year disease free survival (DFS), neck recurrence (NR), complete response (CR), primary tumor emergence (PTE), ipsilateral neck recurrence (INR), contralateral neck recurrence (CNR), severe acute toxicity (RTOG grade $\geq 3$ ) and xerostomia. Editorials, letters to the editor, and review articles were excluded (Figure 1).

\section{Data extraction}

The following items were extracted independently by the two authors (X.M.L. and D.H.L.) from the published articles: year of publication, first author, country, study period, demographic and clinical information on the study patients (age, gender, histology, $\mathrm{N}$ stage, $\mathrm{N}$ level), schedule of treatment, number of patients, outcome results, and follow-up. Any disagreement was resolved through further discussion and including a third author. 


\section{Quality assessment}

The quality of each study was assessed using the Newcastle-Ottawa Quality Assessment Scale (NOS), which considers of the following factors: patient selection, comparability of the study groups, and assessment of outcome $[35,36]$. Each study was assigned a score of between 0 and 9 . Any discrepancies were resolved by discussion. Studies with a score of $>5$ were regarded as high-quality studies.

\section{Statistical analysis}

All the meta-analyses were performed using Review Manager 5.2 (Cochrane Collaboration, Oxford, UK). Each pre-specified outcome was measured in terms of the risk ratios (RRs) [36] and its 95\% confidence intervals (CIs). Two-sided values of $P<0.05$ were considered statistically significant. Heterogeneity among studies was determined by the Chi-square test and an inconsistency $\left(\mathrm{I}^{2}\right)$ statistic of forest plots. $\mathrm{I}^{2}>40 \%$ or $P<0.10$ indicated significant heterogeneity [37]. If there was significant heterogeneity among studies, a random-effects model was used. Otherwise, a fixed-effects model was used [37, 38] .

\section{CONCLUSIONS}

This study suggests that, in patients with NCUP, surgery combined with RT to bilateral neck and PPTS may be the preferable treatment option, as it is associated with improvements in survival and regional control. On the other hand, this recommendation is not based on randomized trials, and one must be alert for severe acute toxicity and xerostomia.

\section{ACKNOWLEDGMENTS}

This work was supported by grants from National Natural Science Foundation of China (81572279, 81001047), University Excellent Young Teachers Program of Guangdong Province (Yq2013040), Natural Science Foundation of Guangdong Province (2015A030313253), and Pearl River Nova Program of Guangzhou City (2014J2200031).

\section{CONFLICTS OF INTEREST}

None.

\section{REFERENCES}

1. Lu X, Hu C, Ji Q, Shen C, Feng Y. Squamous cell carcinoma metastatic to cervical lymph nodes from an unknown primary site: the impact of radiotherapy. Tumori. 2009; 95:185-190.
2. Rodel RM, Matthias C, Blomeyer BD, Wolff HA, Jung K, Christiansen H. Impact of distant metastasis in patients with cervical lymph node metastases from cancer of an unknown primary site. The Annals of otology, rhinology, and laryngology. 2009; 118:662-669.

3. Straetmans J, Vent J, Lacko M, Speel EJ, Huebbers C, Semrau R, Hoebers F, Mujagic Z, Klussmann JP, Preuss SF, Kremer B. Management of neck metastases of unknown primary origin united in two European centers. European Archives of Oto-Rhino-Laryngology. 2015; 272:195-205.

4. Strojan P, Aničin A. Combined surgery and postoperative radiotherapy for cervical lymph node metastases from an unknown primary tumour. Radiotherapy and Oncology. 1998; 49:33-40.

5. Grau C, Johansen LV, Jakobsen J, Geertsen P, Andersen E, Jensen BB. Cervical lymph node metastases from unknown primary tumours: Results from a national survey by the Danish Society for Head and Neck Oncology. Radiotherapy and Oncology. 2000; 55:121-129.

6. Boscolo-Rizzo P, Da Mosto MC, Gava A, Marchiori C. Cervical lymph node metastases from occult squamous cell carcinoma: Analysis of 82 cases. ORL. 2006; 68:189-194.

7. Aslani M, Sultanem K, Voung T, Hier M, Niazi T, Shenouda G. Metastatic carcinoma to the cervical nodes from an unknown head and neck primary site: Is there a need for neck dissection? Head and Neck-Journal for the Sciences and Specialties of the Head and Neck. 2007; 29:585-590.

8. Beldi D, Jereczek-Fossa BA, D’Onofrio A, Gambaro G, Fiore MR, Pia F, Chiesa F, Orecchia R, Krengli M. Role of radiotherapy in the treatment of cervical lymph node metastases from an unknown primary site: Retrospective analysis of 113 patients. International Journal of Radiation Oncology Biology Physics. 2007; 69:1051-1058.

9. Chen AM, Farwell DG, Lau DH, Li BQ, Luu Q, Donald PJ. Radiation therapy in the management of head-and-neck cancer of unknown primary origin: How does the addition of concurrent chemotherapy affect the therapeutic ratio? International Journal of Radiation Oncology Biology Physics. 2011; 81:346-352.

10. Wallace A, Richards GM, Harari PM, Kirwan JM, Morris CG, Katakam H, Mendenhall WM. Head and neck squamous cell carcinoma from an unknown primary site. American Journal of Otolaryngology. 2011; 32:286-290.

11. Fakhrian K, Thamm R, Knapp S, Molls M, Pigorsch S, Haller B, Geinitz H. Radio(chemo)therapy in the management of squamous cell carcinoma of cervical lymph nodes from an unknown primary site: A retrospective analysis. Strahlentherapie und Onkologie. 2012; 188:56-61.

12. Perkins SM, Spencer CR, Chernock RD, Haughey BH, Nussenbaum B, Adkins DR, Kuperman DI, Thorstad WL. Radiotherapeutic management of cervical lymph node metastases from an unknown primary site. Archives of Otolaryngology - Head and Neck Surgery. 2012; 138:656-661. 
13. Weir L, Keane T, Cummings B, Goodman P, O'Sullivan B, Payne D, Warde P. Radiation treatment of cervical lymph node metastases from an unknown primary an analysis of outcome by treatment volume and other prognostic factors. Radiotherapy and Oncology. 1995; 35:206-211.

14. Ligey A, Gentil J, Crehange G, Montbarbon X, Pommier P, Peignaux K, Truc G, Maingon P. Impact of target volumes and radiation technique on loco-regional control and survival for patients with unilateral cervical lymph node metastases from an unknown primary. Radiotherapy and Oncology. 2009; 93:483-487.

15. Reddy SP, Marks JE. Metastatic carcinoma in the cervical lymph nodes from an unknown primary site: Results of bilateral neck plus mucosal irradiation vs. ipsilateral neck irradiation. International Journal of Radiation Oncology Biology Physics. 1997; 37:797-802.

16. Jesse RH, Perez CA, Fletcher GH. Cervical lymph node metastasis: Unknown primary cancer. Cancer. 1973; 31:854-859.

17. Fried MP, Diehl WH, Jr., Brownson RJ, Sessions DG, Ogura JH. Cervical metastasis from an unknown primary. The Annals of otology, rhinology, and laryngology. 1975; 84:152-157.

18. Nordstrom DG, Tewfik HH, Latourette HB. Cervical lymph node metastases from an unknown primary. International Journal of Radiation Oncology Biology Physics. 1979; 5:73-76.

19. Leipzig B, Winter ML, Hokanson JA. Cervical nodal metastases of unknown origin. The Laryngoscope. 1981; 91:593-598.

20. Bataini JP, Rodriguez J, Jaulerry C, Brugere J, Ghossein NA. Treatment of metastatic neck nodes secondary to an occult epidermoid carcinoma of the head and neck. The Laryngoscope. 1987; 97:1080-1084.

21. Harper CS, Mendenhall WM, Parsons JT, Stringer SP, Cassisi NJ, Million RR. Cancer in neck nodes with unknown primary site: role of mucosal radiotherapy. Head \& neck. 1990; 12:463-469.

22. Marcial-Vega VA, Cardenes H, Perez CA, Devineni VR, Simpson JR, Fredrickson JM, Sessions DG, Spector GG, Thawley SE. Cervical metastases from unknown primaries: radiotherapeutic management and appearance of subsequent primaries. International journal of radiation oncology, biology, physics. 1990; 19:919-928.

23. Sinnathamby K, Peters LJ, Laidlaw C, Hughes PG. The occult head and neck primary: to treat or not to treat? Clinical oncology (Royal College of Radiologists (Great Britain)). 1997; 9:322-329.

24. van der Planken HJ, Tiwari RM, Karim AB. Treatment of cervical lymph node metastasis from an unknown primary tumor, with a review of the literature. Strahlentherapie und Onkologie : Organ der Deutschen Rontgengesellschaft [et al]. 1997; 173:163-169.

25. Tong CC, Luk MY, Chow SM, Ngan KC, Lau WH. Cervical nodal metastases from occult primary: undifferentiated carcinoma versus squamous cell carcinoma. Head \& neck. 2002; 24:361-369.

26. Yalin Y, Pingzhang T, Smith GI, Ilankovan V. Management and outcome of cervical lymph nod metastases of unknown primary sites: A retrospective study. British Journal of Oral and Maxillofacial Surgery. 2002; 40:484-487.

27. Zuur CL, van Velthuysen ML, Schornagel JH, Hilgers FJ, Balm AJ. Diagnosis and treatment of isolated neck metastases of adenocarcinomas. European journal of surgical oncology : the journal of the European Society of Surgical Oncology and the British Association of Surgical Oncology. 2002; 28:147-152.

28. Huang CC, Tseng FY, Yeh TH, Wen YH, Hsu CJ, Ko JY, Lou PJ, Chen YS. Prognostic factors of unknown primary head and neck squamous cell carcinoma. OtolaryngologyHead and Neck Surgery. 2008; 139:429-435.

29. Demiroz C, Vainshtein JM, Koukourakis GV, Gutfeld O, Prince ME, Bradford CR, Wolf GT, McLean S, Worden FP, Chepeha DB, Schipper MJ, McHugh JB, Eisbruch A. Head and neck squamous cell carcinoma of unknown primary: Neck dissection and radiotherapy or definitive radiotherapy. Head and Neck-Journal for the Sciences and Specialties of the Head and Neck. 2014; 36:1589-1595.

30. Carlson LS, Fletcher GH, Oswald MJ. Guidelines for radiotherapeutic techniques for cervical metastases from an unknown primary. International journal of radiation oncology, biology, physics. 1986; 12:2101-2110.

31. Glynne-Jones RG, Anand AK, Young TE, Berry RJ. Metastatic carcinoma in the cervical lymph nodes from an occult primary: a conservative approach to the role of radiotherapy. International journal of radiation oncology, biology, physics. 1990; 18:289-294.

32. Colletier PJ, Garden AS, Morrison WH, Goepfert H, Geara F, Ang KK. Postoperative radiation for squamous cell carcinoma metastatic to cervical lymph nodes from an unknown primary site: outcomes and patterns of failure. Head \& neck. 1998; 20:674-681.

33. McMahon J, Hruby G, O’Brien CJ, McNeil EB, Bagia JS, Clifford AR, Jackson MA. Neck dissection and ipsilateral radiotherapy in the management of cervical metastatic carcinoma from an unknown primary. The Australian and New Zealand journal of surgery. 2000; 70:263-268.

34. Network NCC. Head and Neck Cancer V.1.2015,NCCN clinical practice guidelines in oncology. 2015.

35. GA Wells BS, D O'Connell, et al. The Newcastle-Ottawa Scale(NOS)for assessing the quality of nonrandomised studies inmeta-analyses. Ottawa Hospital Research Institute Web site. 2015; http://www.ohri.ca/programs/clinical_ epidemiology/oxford.asp:Accessed October. 25; 2015.

36. Myers ER, Moorman P, Gierisch JM, Havrilesky LJ, Grimm LJ, Ghate S, Davidson B, Mongtomery RC, Crowley MJ, McCrory DC, Kendrick A, Sanders GD. Benefits and Harms of Breast Cancer Screening: A Systematic Review. Jama. 2015; 314:1615-1634. 
37. Tu J, Wang S, Huo Z, Lin Y, Li X, Wang S. Recombinant human thyrotropin-aided versus thyroid hormone withdrawal-aided radioiodine treatment for differentiated thyroid cancer after total thyroidectomy: a meta-analysis. Radiotherapy and oncology. 2014; 110:25-30.
38. Ward C, Witham M. Cochrane handbook for systematic reviews of interventions. Cochrane Book. 2010. 